\title{
ROLE OF TAX REVENUE TO STRENGTHEN OF POKHARA SUB-METROPOLITAN CORPORATION
}

\author{
Devilal Sharma
}

\begin{abstract}
s
After the restoration of the democracy in Nepal, the demand for spending up decentralization process has been gained ground. As a result of increasingly assertive role of stakeholders, the enactment of local selfgovernance Act (LSGA), 1999 in line with 9th plan, objective had been achieved providing the base for further promotion of decentralization framework in the country. Municipal financing is new concept in Nepal. Municipal financing indicates the study of various sources of revenue (both internal and external) and their collection, allocation, mobilization and utilization of those resource in such a manner that ultimate municipal goal can be achieved through it. For sustainable development effort conducted by local government to realized revenue and evaluation such performance was done through field surveys and on the basis of existing available data and reports. Simple tabular presentation percentage tools is used to analyzed data and found PSMC is not success to collect sufficient tax revenue as its possibilities.
\end{abstract}

Key Words:Integrated Property Tax (IPT), Local Self Governance Act (LSGA), Revenue, Vehicle Tax, Business Tax, Rent Tax, Octori

\section{Background of the study}

Nepal is a small, least developed and land locked country situated between two large country China and India. It has a lot of challenges as well as prospectus too. PSMC, is situated on the southern foot of Annapurna Himalayan range, is the second largest urban center of Nepal (Brochure, 1998). Pokhara is known for its panoramic view of Annapurna Himalayan range, fresh water lakes, river gorges, natural caves and unique socio cultural heritage of Himalayan inhabitants. Total area of PSMC is covered $55.66 \mathrm{sq} . \mathrm{km}$. with valley floor of $123 \mathrm{sq} . \mathrm{km}$. This valley is situated at an elevation ranges from 627 meter to 980 meter above sea level (Brochure, 1998).

After the restoration of the democracy in Nepal, the demand for spending up decentralization process has been gained ground. As a result of increasingly assertive role of stakeholders, the enactment of local self-governance Act (LSGA), 1999 in line with $9^{\text {th }}$ plan, objective had been achieved providing the base for further promotion of decentralization framework in the country. LSGA and its regulation have been 
Janapriya Journal of Interdisciplinary Studies, Vol. 2, No.1 (December 2013)

set up the potential for an expanded set of service responsibilities for Nepal's local governments (LGS), which consists of 75 district development committees (DDCs), 58 municipalities and 3913 village development committed (VDCs)(Bhurtel,2001). A lot of fund is spend by the public authority for the protection a common people and for the creation a various socio-economic infrastructures. The government needs a lot of money to run it successfully. The money that is so much important to the government is called public revenue collected from external and internal sources.

External sources of fund are foreign grants and loans. This type of fund is received from government of foreign countries and international organizations. This type of fund is more important for undeveloped and underdeveloped countries. It is used for economic development, reconstruction and foreign exchange to recover from crisis conditions for productive uses. But external sources are not good for healthy development of nation. It is better to mobilize internal sources rather than the donors. But Nepal's past experience shows that had mobilized internal resources lower than expected.

Internal sources of the fund include both tax and non-tax revenue. The government receives tax revenue as a compulsory payment when non-tax revenue is a conditional source. Non-tax sources are uncertain and inconvenient because they are imposed according to the necessary to the government. So, taxes are the better sources of public revenue. The use of taxes is safer for financing public revenue is developing countries. So, tax revenue had been taken as the best effective tool for raising the public fund.

Tax is a compulsory contribution from the persons to the government without getting corresponding benefit of a good or serviced providing by the government persons, who pays tax, does not get any equivalent benefit from the government. It is a compulsory liability of the person who has to pay tax.

In other hands, The Local Self Governance Act (LSGA), promulgate in 1999, has given legal authority to municipalities to levy house and land tax, or Integrated Property Tax (IPT). IPT is a municipal land and property based tax, which bears greater revenue potential and higher buoyancy. It is being successfully implemented in many municipalities of Nepal. Municipalities have the right to levy (IPT) in lieu of House and Land Tax (HALT) and land revenue tax. IPT/ HALT has become the most important own source income for most municipalities. Still, IPT coverage is comparatively poor and needs to be improved in order to strengthen municipal own source revenues and reduce the dependency of the cities from the national transfer system.

As per LSGA, there is a choice for municipalities either to implement IPT or HALT with land revenue tax. As a result of Nepal's accession to the World Trade Organization (WTO) in 2004, Local Development Fee as the major income source for the country's 58 municipalities has to be abolished latest in 2011. The local Development Fee is including $74.19 \%$ of all direct taxes in the municipalities' local revenue structure. With this upcoming challenge the mobilization of resources and the improvement of the municipalities' Own Source Revenue (OSR) collection are major upcoming challenges. The full-fileged implementation of IPT/HALT as the most promising source of income is one of the core areas of the ongoing discussion on how to improve the OSR collection 
of the municipalities in Nepal. The Octori is a unique tax levied extensively is South Asia. It is an internal trade tax levied by municipalities on all goods entering into local jurisdiction. In Nepal the tax was assessed on the value, weight or number of items and was collected through collection agents at Octori stations. (Kelly,1998).

\section{Research Problem}

In the world most of the developing countries including Nepal should make heavy investment of infrastructure and social and economic activities $\mathrm{n}$ the development of the nation. It needs huge amount of capital for the economic development various measures adopted by the government to boost revenue collection. There is still a substantial resource gap between expenditure and revenue collection. The rate of government expenditure is exceeding the rate of growth revenue from the beginning of its development prose. So, the development of countries will be possible only when the government can collect its own internal revenue that consists tax and nontax revenue. Tax and non-tax revenue amount for 79.059 percent and 20.94 percent respectively in fiscal year 2064/65 (Paudel, 2010). Thus, evident that the major portion of government revenue is covered by Tax revenue. In this regards it is based on Pokhara sub-metropolitan city (PSMPC). There are various problems to local tax collection in PSMPC. This study is focuses on the local tax contribution in local government and is the local tax administration is effective?

\section{Objectives of the study}

The main objectives of the study is to examine the role of tax to strengthen the local government and to give appropriate suggestions to improve it's system. In addition to that objective the study is focused to review the local tax structure of PSMPC and to analyze the contribution of local tax to local government.

\section{Methodology used}

Research design is a framework that keeps the researcher in a particular track. It is a logical and systematic plan prepared for directing a research study. In other word, a research design is the specification of methods and procedures for acquiring their formulation needed. Therefore, to achieve that desired end of this study descriptive and analytical research design is approved. The present local tax revenue of PSMC activities are the population of this study. Similarly this study will be covered as sample from fiscal year 2062/063 to 2066/067. In this study most of the data were collected from secondary source major source of data are PSMC office Pokhara, and other related books, journal, newspaper, reports etc. Secondary as well as primary source of data will be collected in order to achieve the real and actual result of this research.

\section{Discussion and Analysis}

Data and information as availed by PSMC regarding tax collection under various sources as well as sector wise analysis of that tax toward total tax revenue found as: 
Table: 1

Land Revenue Tax Collection Trend and it's contribution on Total Revenue of Local government

(in Rs.'000)

\begin{tabular}{|l|l|l|l|}
\hline Fiscal Year & Total Tax Revenue & Land Revenue Tax & Contribution \% \\
\hline $2062 / 063$ & $82,574.21$ & 1035.81 & 1.25 \\
\hline $2063 / 064$ & 47070.11 & 1561.43 & 3.32 \\
\hline $2064 / 065$ & 89211.37 & 1741.10 & 1.95 \\
\hline $2065 / 066$ & 182010.00 & 2068.85 & 1.14 \\
\hline $2066 / 067$ & 194964.00 & 2490.118 & 1.85 \\
\hline
\end{tabular}

Source: Revenue Section, PSMC.

From the above table it shows that the percentage contribution over total tax revenue of Land Revenue Tax yield. The scenario shows the fluctuating condition of revenue collection. In fiscal year 2063/064 was the highest contribution i.e. 3.32\%. The minimum contribution was $1.14 \%$ in fiscal year 2065/066.

Table: 2

House and Land Tax Collection Trend and it's contribution on Local government (in Rs.'000)

\begin{tabular}{|l|l|l|l|}
\hline \multicolumn{1}{|c|}{ Fiscal Year } & \multicolumn{1}{c|}{ Total Tax Revenue } & \multicolumn{1}{c|}{ House and Land Tax } & Contribution \% \\
\hline $2062 / 063$ & 32574.21 & 12468.69 & 15.1 \\
\hline $2063 / 064$ & 47070.11 & 11635.37 & 24.72 \\
\hline $2064 / 065$ & 89211.37 & 12190.94 & 13.7 \\
\hline $2065 / 066$ & 182010.00 & 21826.035 & 12 \\
\hline $2066 / 067$ & 194964.00 & 18727.946 & 9.61 \\
\hline
\end{tabular}

Source: Revenue Section, PSMC.

From the above table it shows that the contribution over total tax revenue of House and Land Tax. The scenario shows the fluctuating condition of revenue collection. In fiscal year $2063 / 064$ was the highest contribution i.e. $24.72 \%$. The minimum contribution was $9.61 \%$ in fiscal year 2066/067.

Table: 3

Rent Tax (House and Land) Tax and It's contribution on total revenue of local government / PSMC (in Rs.'000)

\begin{tabular}{|l|l|l|l|}
\hline Fiscal Year & Total Tax Revenue & Rent Tax of House \& Land & Contribution \% \\
\hline $2062 / 063$ & 32574.21 & 215.933 & 2.62 \\
\hline $2063 / 064$ & 47070.11 & 547.201 & 1.16 \\
\hline
\end{tabular}


Janapriya Journal of Interdisciplinary Studies, Vol. 2, No.1 (December 2013)

\begin{tabular}{|l|l|l|l|}
\hline $2064 / 065$ & 89211.37 & 421.028 & 4.72 \\
\hline $2065 / 066$ & 182010.00 & 201.087 & 1.10 \\
\hline $2066 / 067$ & 194964.00 & 210.204 & 1.08 \\
\hline
\end{tabular}

Source: Revenue Section, PSMC.

From the above table it shows that the percentage contribution over total tax revenue of Rent tax of House and Land. This kind of tax's contribution shows fluctuation also. In fiscal year 2064/065 was the highest contribution. The minimum contribution was 1.08 in fiscal year 2066/067.

Table: 4

Rent / Bitauri Tax and it's contribution on Total Revenue of Local government (in Rs.'000)

\begin{tabular}{|l|l|l|l|}
\hline Fiscal Year & Total Tax Revenue & Rent Tax/Bitauri Tax & Contribution \% \\
\hline $2062 / 063$ & 82574.21 & 50.00 & 0.06 \\
\hline $2063 / 064$ & 47070.11 & 103.6 & 0.22 \\
\hline $2064 / 065$ & 89211.37 & 708.09 & 0.8 \\
\hline $2065 / 066$ & 182010.00 & - & - \\
\hline $2066 / 067$ & 194964.00 & 323.525 & 0.166 \\
\hline
\end{tabular}

Source: Revenue Section, PSMC.

From the above table it shows that the percentage contribution over total tax revenue of Rent / Bitauri Tax yield. The scenario shows the fluctuating condition of revenue collection. In fiscal year 2064/065 was the highest contribution i.e. $0.8 \%$. In fiscal year 2065/066 there was no any contribution of Rent / Bitauri tax to Local government.

Table: 5

Business Tax and It's contribution on Total Revenue of Local government (in Rs.'000)

\begin{tabular}{|l|l|l|l|}
\hline Fiscal Year & Total Tax Revenue & Business Tax & Contribution \% \\
\hline $2062 / 063$ & $82,574.21$ & 1859.014 & 2.25 \\
\hline $2063 / 064$ & 47070.11 & 2470.053 & 5.25 \\
\hline $2064 / 065$ & 89211.37 & 2888.37 & 3.24 \\
\hline $2065 / 066$ & 182010.00 & 5807.405 & 3.19 \\
\hline $2066 / 067$ & 194964.00 & 5015.9 & 2.6 \\
\hline
\end{tabular}

Source: Revenue Section, PSMC.

From the above table it shows that the contribution over total tax revenue of Business Tax yield. The above scenario shows the fluctuating condition of revenue collection. Fiscal year 2063/064 was the highest contribution of Business tax and the lowest 
Janapriya Journal of Interdisciplinary Studies, Vol. 2, No.1 (December 2013)

contribution percentage was $2.25 \%$ in fiscal year 2062/063.

Table: 6

Vehicle Tax and It's contribution on Total Revenue of Local government (in Rs.'000)

\begin{tabular}{|c|c|c|c|}
\hline Fiscal Year & Total Tax Revenue & Vehicle Tax & Contribution \% \\
\hline $2062 / 063$ & 82574.21 & 1377.27 & 1.67 \\
\hline $2063 / 064$ & 47070.11 & 1235.36 & 2.62 \\
\hline $2064 / 065$ & 89211.37 & 1272.8 & 1.43 \\
\hline $2065 / 066$ & 182010.00 & 870.12 & 0.48 \\
\hline & 194964.00 & 385.213 & 1.98 \\
\hline
\end{tabular}

Source: Revenue Section, PSMC.

From the above table it shows that the contribution over total revenue of vehicle tax yield. The above scenario shows the fluctuating condition of revenue collection. Fiscal year 2063/064 was the highest contribution of vehicle tax and total revenue of PSMC i.e. $2.62 \%$ and the lowest contribution was $0.48 \%$ in fiscal year $2065 / 066$.

$$
\text { Table: } 7
$$

Entertainment Tax and It's contribution on Total revenue of PSMC (in Rs.'000)

\begin{tabular}{|c|c|c|c|}
\hline Fiscal Year & Total Tax Revenue & Entertainment Tax & Contribution \% \\
\hline $2062 / 063$ & $82,574.21$ & 354.813 & 0.43 \\
\hline $2063 / 064$ & 47070.11 & 402.92 & 0.86 \\
\hline $2064 / 065$ & 89211.37 & 359.6 & 0.40 \\
\hline $2065 / 066$ & 182010.00 & 498.42 & 0.27 \\
\hline $2066 / 067$ & 194964.00 & 390.42 & 0.20 \\
\hline
\end{tabular}

Source: Revenue Section, PSMC.

From the above table it shows that the contribution over total revenue of Entertainment Tax yield. The contribution of Entertainment Tax on Local government shows the fluctuating condition of revenue collection. Fiscal year 2063/064 was the highest contribution of this tax. The lowest contribution was $020 \%$ in fiscal year 2066/067.

Table: 8

Advertisement Tax and It's contribution on Total revenue of PSMC (in Rs.'000)

\begin{tabular}{|c|c|c|c|}
\hline Fiscal Year & Total Tax Revenue & Advertisement Tax & Contribution \% \\
\hline $2062 / 063$ & $82,574.21$ & 58.96 & 0.71 \\
\hline $2063 / 064$ & 47070.11 & - & - \\
\hline $2064 / 065$ & 89211.37 & 575.14 & 1.09 \\
\hline
\end{tabular}




\begin{tabular}{|l|l|l|l|}
\hline $2065 / 066$ & 182010.00 & 438.08 & 0.24 \\
\hline $2066 / 067$ & 194964.00 & 417.81 & 0.21 \\
\hline
\end{tabular}

Source: Revenue Section, PSMC.

From the above table it clearly shows that the contribution over total revenue of Advertisement Tax on Local government. The data shows the fluctuation condition of revenue collection. Fiscal year 2064/065 was the highest contribution of this tax i.e. $1.09 \%$ and there are not any contribution in fiscal year 2063/064. Then after fiscal year $2066 / 067$ was the lowest contribution i.e. $0.21 \%$.

Table: 9

Due Octroi Tax / Chungi Tax and It's contribution on Total Tax revenue of PSMC (in Rs.'000)

\begin{tabular}{|c|c|c|c|}
\hline Fiscal Year & Total Tax Revenue & Octroi Tax & Contribution \% \\
\hline $2062 / 063$ & $82,574.21$ & - & - \\
\hline $2063 / 064$ & 47070.11 & - & - \\
\hline $2064 / 065$ & 89211.37 & - & - \\
\hline $2065 / 066$ & 182010.00 & - & - \\
\hline $2066 / 067$ & 194964.00 & 300.00 & 0.15 \\
\hline
\end{tabular}

Source: Revenue Section, PSMC.

From the above table it clearly shows that the contribution over total revenue of octroi tax yield. The contribution of Due octroi tax on Local government shows the poor condition. Only fiscal year 2066/067 have to be a success to obtain this kind of tax. This trend shows that it is necessary to focus to obtain this kind of tax.

\section{Major Finding of the Study}

- The LSGA mentions the two options of local property taxes levied by municipality referring to rule 136 land revenue/ House and land tax and IPT.

- Land revenue tax is levied upon land, HALT is levied upon the net taxable value of real estate and the plot on which the real estate is located and IPT is levied upon land and building combined, based on total net taxable valuation of the property.

- IPT/ HALT taxed by two district assessment methodologies i.e. area based and value based assessment.

- There is fluctuation is total internal revenue trend in study period. In fiscal year 2064/067 and 2065/066 has highest progress achievement that was $73.40 \%$ and $73.62 \%$ respectively. The lowest achievement was $37.25 \%$ in fiscal year 2063/064 .

- Among all of local taxes only business or progression tax collection trend is increasingly position up to FY 2065/066. Then after it is decreased due to lack of effectiveness of PSMC.

- Advertisement tax collection progress is also zero in FY 2063/064 due to lack of 
Janapriya Journal of Interdisciplinary Studies, Vol. 2, No.1 (December 2013)

effectiveness of PSMC.

- PSMC is unable to collect due octroi tax except FY 2066/067.

- Contribution of local taxes in total tax revenue is PSMC is fluctuating condition.

- Major source of local taxes in contribution of total revenue of PSMC is house and land tax. Highest contribution of this kind of tax in fiscal year 2063/064 i.e. $24.72 \%$.

- Among all local taxes, environment tax and advertisement taxes has lowest contribution to total revenue of PSMC. It is necessary to improve that kind of tax collection trend.

\section{Conclusions}

Collection efficiency of PSMC is not satisfactory. This is due to the ad-hoc budgeting inefficient tax administration and frequent internal disputes. PSMC is unable to collect revenues as budget. PSMC is not property mobilizing revenue from local taxes and other internal sources. Tax collection procedures of municipality are not effective. Therefore, tax payers are not paying their liabilities regularly. PSMC is unable to collect minimum level of potential tax. The total tax collection progress ranges was to $73.62 \%$ to $37.25 \%$. This shows that, PSMC used to project the revenue unscientifically. The actual local tax is also fluctuating during the study period. The contribution of local tax to the revenue of local government ranges $24.72 \%$ to $0.15 \%$. This scenario shows that, PSMC used to project the local tax unscientifically as well as faulty collection procedures.. PSMC has not established coordination with stakeholders. Pokhara Chamber of Commerce and Industry, business man, local intellectual, other government and non governmental organization and donor agencies etc. PSMC has neglected private sector in resource mobilization service delivery and infrastructure development. There is lack of political commitment and coordination with stakeholders in PSMC. Revenue administration of PSMC is very poor. There is lack of motivated qualified and trained staffs and clear cut job description. PSMC has neither updated tax roll nor dispatched tax liability to the tax payer. There is not effective collection procedure. Revenue of PSMC on local taxes is increasing but not sufficiently to meet the financial requirements. There is much scope for the better mobilization of local resources for the local development.

\section{Recommendation}

On the basis of the conclusions drawn through this research work, the following recommendations have been forwarded for the further improvement the local tax yield of PSMC.

PSMC should launch awareness program to all the local people or tax payers about the local taxes. Different programs should be applied for awareness comparing such as, notice in news papers, municipal notice/ letter, miking and effective mobilize the door step collection teams. Municipality should launch motivational activities for registration with PSMC and encourage paying tax. Advance and effective billing system should be better for informing taxpayers about their tax liability. PSMC should start to formulate and enactation revenue improvement action plan (RIAP) and the punishment standard for action against tax defaulters. PSMC should improve present tax assessment system. It should consult with clamber of commerce as well as other related parties for tax 58 
Janapriya Journal of Interdisciplinary Studies, Vol. 2, No.1 (December 2013)

assessment procedures. PSMC should give the different motivational training and rewards into their tax collection employees as well as punishment should be taken for those who become tax defaulters. So, it is recommended that the PSMC should arrange the financial data as prescribed by LSG 1999 and make them up to date.

\section{References:}

Bhattarai, I. \& Koirala, G.P. (2066). Taxation in Nepal. Kathmandu: Asmita Publication.

Kandel, P. R. (2063). Taxation of Nepal. Kathmandu: Buddha Academic Publishers Sand Distributors Pvt. Ltd.

Wolff, H. K. \& Pant P. R. (2003). Social Science Research and Thesis Writing. $3^{\text {rd }}$ ed. Kathmandu: Publishers and Distribution Pvt. Ltd.

Adhikari, T. P. (2004). Financial Analysis of Pokhara Sub-Municipal Corporation. Unpublished Master degree's Dissertation Department of Management., Tribhuvan University.

Budhathoki, K. K. (2002). Financial Analysis and Forecasting of Pokhara Submunicipal Corporation. Unpublished Master Degree's Dissertation. Department of management. P.N. Campus, Tribhuvan University.

Dhungana, S. (2003). Rural Urban Partnership Program. Unpublished Master Degree's Dissertation. Department of Management Tribhuvan University.

Gurung, S. (2004). The Financial Implication of the Proper Management of Recycle and Reusable Waste: A Case Study of PSMC. Unpublished Master Degree's Dissertation. Department of Management, P.N. Campus, Tribhuvan University.

Sapkota, H. C. (2002). Local Government Finance in Nepal: A Case Study of PSMC. Unpublished Master Degree's Dissertation. Department of Economics, Tribhuvan University.

Sigdel, Bimal (2008). Financial Analysis of Local Government: A Case Study of Tanahun District Development Committee. Unpublished master degree's dissertation. Department of Management. P.N. campus, Tribhuvan University.

Subedi, M. (2005). Local Government Financial Management: A Case Study of Kaski District Development Committee. Unpublished Master Degree's Dissertation. Department of Economic, P.N. campus, Tribhuvan University.

Baral, K. J. (2005). The Municipal Expenditure and Revenue Structure in Nepal. Economic Literature. P.N. Campus, Vol. VI.2.

Bird, R. M.\& Slack, E. (2002). Land and Property Taxation: A Review Journal of Tax Assessment and Administration. Vol.7 No. 3.

GON, (2055). Local Self-Governance Act. Nepal Gazette. Kathmandu.

Kelly, R. (1998). Intergovernmental Revenue Allocation. Theory and Practice: Application to Nepal. Development Discussion Paper, No. 624. 
Janapriya Journal of Interdisciplinary Studies, Vol. 2, No.1 (December 2013)

PSMC (1998). Pokhara Sub-metropolitan City An Introduction Pokhara

PSMC (2009). Annual Bulletin of Pokhara Sub-Municipal Corporation.

PSMC (2010). Annual Bulletin of Pokhara Sub-Municipal Corporation.

GON, Nepal (2052). Ministry of Local Development: A Report on Study of Alternative of Octori. Kathmandu: MLC/ UDLE.

GON (2055). Local Self-Governance Act. Nepal, Gazette, Kathmandu.

GON (2056). Local Self Governance Regulation Nepal Gazette Kathmandu.

GON/ Nepal (2019). Nagar Panchayat Act. Nepal Gazette Kathmandu.

GON/ Nepal. (2020). Magar Panchyat Working Management Regulation. Nepal Gazette, Kathmandu.

$<$ http://www.udenepal.org/report/financialreports/municpalfinance $>$ 